\title{
Quantitative Evaluation of Various Preparations and Extracts of the Male Contraceptive Justicia gendarussa and Identification of a New Aminobenzyl Derivative
}

\section{(ㄷ)(i) (우 $\ominus$}

\author{
Authors
}

Mariam M. Mnatsakanyan ${ }^{1}$, Emerson F. Queiroz ${ }^{1}$, Laurence Marcourt ${ }^{1}$, Bambang E. W. Prajogo ${ }^{2}$, Jean-Luc Wolfender ${ }^{1}$

\begin{abstract}
Justicia gendarussa is a medicinal plant found in different regions of Indonesia and used in decoctions by Papuan tribes to reduce male fertility. An enriched ethanolic extract of this plant has been used in the frame of clinical trials in Indonesia to evaluate its male contraceptive activity. Previous studies have indicated that the flavonoid gendarusin A may have a role in the male contraception properties of this plant. In addition, the level of aminobenzyl derivatives was lowered as a safety precaution. In order to obtain a comprehensive chemical profile of the methanolic plant extract, it was analysed by HPLC-PDAESI-MS and UHPLC-TOF-HRMS. The same method was also applied to profile extracts of the same plant material from different Indonesian regions, a water decoction used traditionally, and the enriched extract used in clinical trials. This allowed for the dereplication of all previously known flavonoids and newly reported amides, and permitted highlighting the presence of the potentially new aminobenzyl derivative. Targeted isolation of this new amide was performed using medium-pressure liquid chromatography. NMR and HRMS allowed for the establishment of the identity of the novel compound. The same procedure was used to obtain pure standards for quantitative studies. Quantitation of the major compounds was performed for different extracts using HPLC-UV. Significant differences were observed between the samples. Although gendarusin A was the main compound in all samples, it occurred in different amounts in the batches of dried material obtained from different Indonesian regions. The enriched extract contained mainly gendarusin A, as did the traditional decoction, but the level of the aminobenzyl derivatives was significantly lower.
\end{abstract}

\section{Introduction}

Justicia gendarussa Burm. F. (Acanthaceae) is a medicinal plant found in Sri-Lanka, India, Malaysia, the Philippines, and Indonesia [1]. Traditionally, the leaves have been used for many illnesses, in- cluding rheumatoid gout, arthritis, asthma, vaginal discharges, and headache [2-5], and their anti-inflammatory, analgesic [6], antioxidant, and hepatoprotective activities [7] have also been reported. Particularly remarkable is the male fertility reducing activity of 

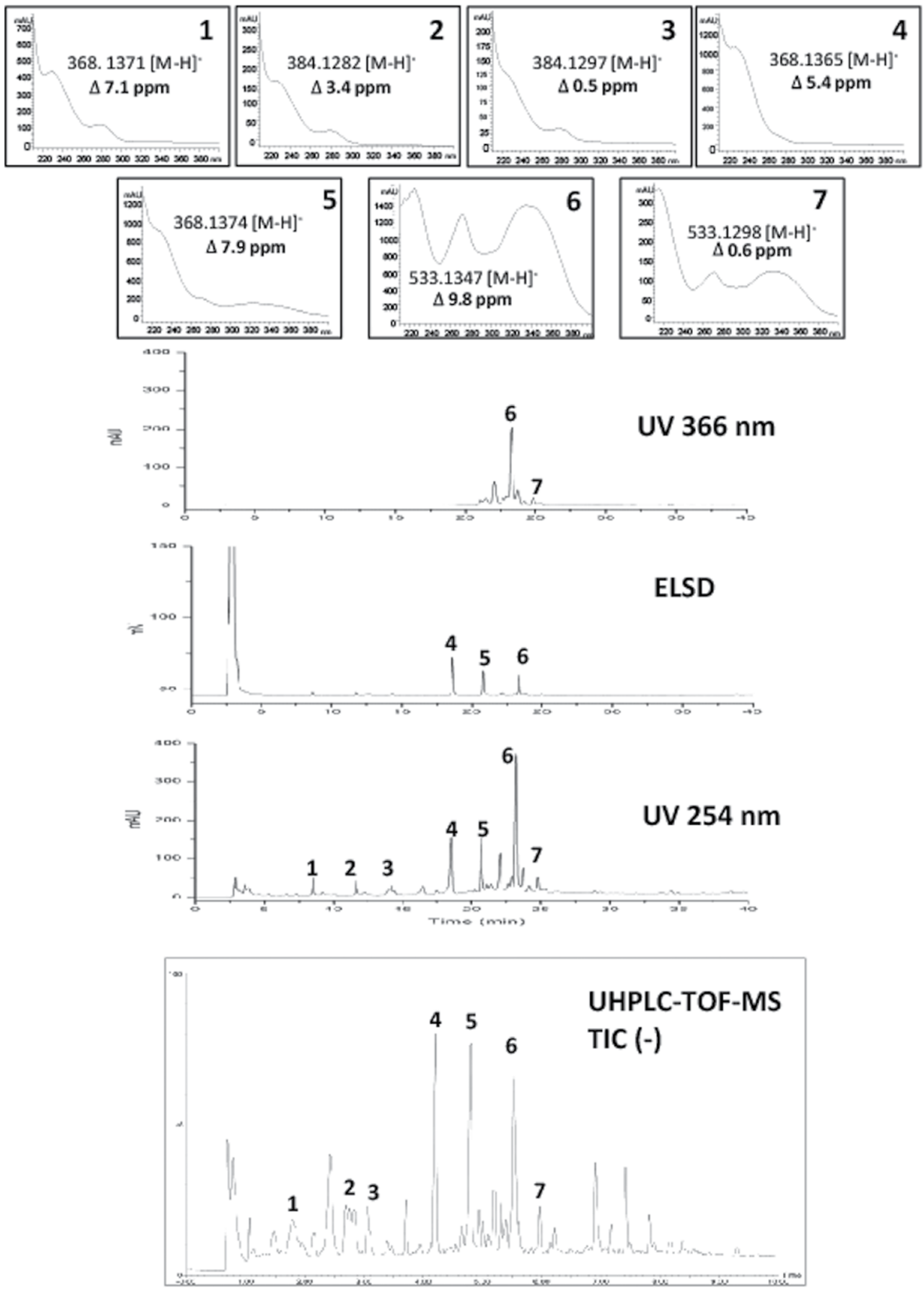

- Fig. 1 HPLC-PDA-ELSD analysis of J. gendarussa methanol extract. 


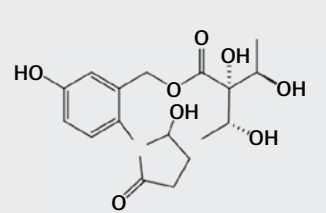

๘
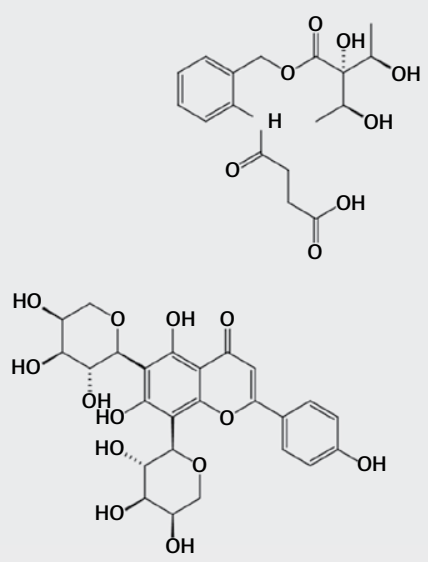

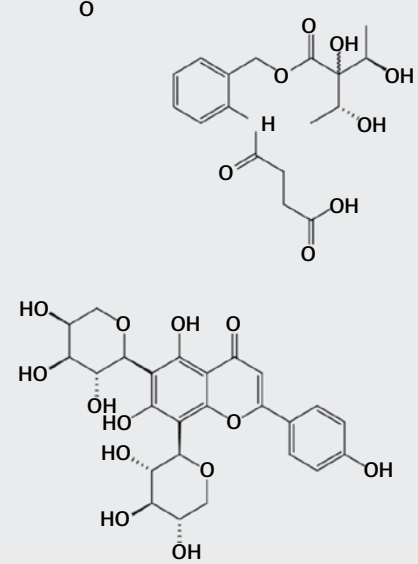

- Fig. 2 Compounds isolated from J. gendarussa methanol extract.

- Table 1 Linear range, LOD, and LOQ of the three compounds $(n=6)$.

\begin{tabular}{|c|c|c|c|c|c|c|}
\hline Compound $^{a}$ & $\begin{array}{l}\text { Linearity range } \\
(\mu \mathrm{g} / \mathrm{mL})\end{array}$ & Calibration equation $^{\mathrm{b}}$ & LOQ $(\mu \mathrm{g} / \mathrm{mL})^{\mathrm{c}}$ & LOD $(\mu \mathrm{g} / \mathrm{mL})^{\mathrm{c}}$ & $\mathbf{R}^{2 \mathrm{~d}}$ & RSD $^{\mathrm{e}}$ \\
\hline 4 & $1-800$ & $y=695.45 x-12.682$ & 0.024 & 0.008 & 0.999 & 1.74 \\
\hline 5 & $1-500$ & $y=167.95 x+16.155$ & 0.119 & 0.03 & 0.997 & 2.01 \\
\hline 6 & $1-100$ & $y=98.195 x+1.316$ & 0.889 & 0.293 & 0.998 & 8.73 \\
\hline
\end{tabular}

J. gendarussa leaves, used traditionally by the Indonesian Papuan people for male contraception [8,9]. Apart from knowledge of it being used as a water decoction, there are, unfortunately, few documented details about the traditional preparations [9, 10].

The male contraceptive properties have gained interest in Indonesia for phytochemical and pharmacological investigations. An ethanolic leaf extract of J. gendarussa obtained from the Pacet region (Indonesia) was phytochemically investigated and 6,8-di-C$\alpha$-L-arabinocylapigenin (gendarusin A) was identified as the major constituent $[11,12]$. Also identified was another less abundant flavonoid, C glycoside gendarusin B (6-C- $\alpha$-L-arabinocyl-8-C- $\beta$-Dxylocilapigenin) $[11,12]$, and more recently, unusual 2 -aminobenzyl derivatives (justidrusamides A-D) [13]. O-Substituted aromatic amines [14], $\beta$-sitosterol, lupenol, and fridelin [15] were reported to be present in J. gendarussa collected in India.

Gendarusin A was reported to reversibly inhibit the activity of spermatozoa hyaluronidase activity $[11,12]$, which is a facilitating enzyme for sperm penetration during in vitro fertilisation $[11,16]$; therefore, gendarusin $\mathrm{A}$ is considered to be the active constituent for the male contraceptive property of J. gendarussa. Currently, the gendarusin A flavonoid-enriched extract of J. gendarussa leaves is reportedly under clinical trials as a male contraceptive in Indonesia
[12]. These extracts undergo an extensive "cleaning" standardisation process to improve their safety profile $[12,17]$.

Given the fact that the plant is also used by Papuans without any pretreatment, we thought comparative chemical profiling of the enriched extracts and the traditional water decoction was important to underline any chemical differences. We compared different J. gendarussa samples from other regions for the presence of the active compound and other major constituents to facilitate the future selection of J. gendarussa plant specimens with the highest content of the active constituent for cultivation. The extracts of J. gendarussa leaves collected in different regions of Indonesia as well as traditional water decoctions and enriched extracts were comparatively profiled for their main active constituent content (gendarusin A) and other major chemical markers. In the absence of available certified reference standards, the main active constituent flavonoid (gendarusin $A$ ), another main flavonoid (gendaru$\sin B$ ), and amide constituents (justidrusamides A-D) were isolated for use as standards for the quantitation. A detailed comparison of the traditional decoction and the enriched extract was established and the content of the main compounds in J. gendarussa from various regions of Indonesia was compared from a quantitative view point. 


\section{Results and Discussion}

In order to obtain a detailed survey of the composition of the leaves of J. gendarussa, a preliminary metabolite profiling was performed on the methanol leaf extract (see experiment) using reversedphase HPLC-PDA-ESI-MS and high-resolution UHPLC-TOF-HRMS ( $\triangleright$ Fig. 1). The evaporative light scattering detector (ELSD) trace revealed that three main constituent peaks, 4 [retention time (RT) $18.62 \mathrm{~min}$ ], 5 (RT $20.67 \mathrm{~min}$ ), and 6 (RT $23.31 \mathrm{~min}$ ), were present

- Table 2 Inter-day and intraday precision of the method $(n=6)$.

\begin{tabular}{|c|c|c|}
\hline $\begin{array}{l}\text { Reference standard } \\
\text { concentrations }(\mu \mathrm{g} / \mathrm{mL}) \text { a }\end{array}$ & $\begin{array}{c}\text { Inter-day }{ }^{\mathrm{b}} \text { RT }^{\mathrm{c}} \\
\text { RSD }^{\mathrm{d}} \text { Area }^{\mathrm{e}} \text { RSD }\end{array}$ & $\begin{array}{c}\text { Intraday }{ }^{\mathrm{b} T} \\
\text { RSD Area RSD }\end{array}$ \\
\hline \multicolumn{3}{|l|}{ Compound $\mathbf{4}$} \\
\hline 0.5 & $\begin{array}{c}18.680 .0631 .63 \\
2.67\end{array}$ & $\begin{array}{c}18.650 .03 \\
29.6312 .82\end{array}$ \\
\hline 300 & $\begin{array}{c}18.670 .091999 .4 \\
1.21\end{array}$ & $\begin{array}{c}18.630 .04 \\
1446.21 .97\end{array}$ \\
\hline 800 & $\begin{array}{c}18.650 .065555 .32 \\
2.11\end{array}$ & $\begin{array}{c}18.590 .04 \\
5066.70 .89\end{array}$ \\
\hline \multicolumn{3}{|l|}{ Compound $\mathbf{5}$} \\
\hline 5 & $\begin{array}{c}20.720 .0710 .46 \\
2.06\end{array}$ & $\begin{array}{l}20.820 .08 \\
7.254 .83\end{array}$ \\
\hline 50 & $\begin{array}{c}20.710 .11108 .56 \\
1.53\end{array}$ & $\begin{array}{l}20.690 .06 \\
85.961 .56\end{array}$ \\
\hline 300 & $\begin{array}{c}20.660 .01517 .76 \\
2.28\end{array}$ & $\begin{array}{c}20.660 .01 \\
528.752 .27\end{array}$ \\
\hline \multicolumn{3}{|l|}{ Compound 6} \\
\hline 1 & 23.440 .195 .52 .40 & $\begin{array}{l}23.420 .19 \\
5.532 .95\end{array}$ \\
\hline 10 & $\begin{array}{c}23.420 .2611 .13 \\
1.13\end{array}$ & $\begin{array}{l}23.460 .03 \\
12.352 .88\end{array}$ \\
\hline 100 & $\begin{array}{c}23.400 .1892 .2 \\
0.44\end{array}$ & $\begin{array}{c}23.340 .17 \\
105.872 .83\end{array}$ \\
\hline \multicolumn{3}{|c|}{$\begin{array}{l}\text { a4 - Justidrusamide A, } 5 \text { - justidrusamide B, } 6 \text { - gendarusin A. } \\
\text { bInter-day analyses were carried out in duplicate within } 3 \text { days } \\
(n=6) \text {, and intraday analyses were carried in six replicates within a } \\
\text { single day }(n=6) \text {. cMean retention time (min). dRelative standard } \\
\text { deviation (\%). ePeak mean area }\end{array}$} \\
\hline
\end{tabular}

> Table 3 Recovery studies of justidrusamide A (4), justidrusamide B (5), and gendarusin $A(6)$ from the J. gendarussa extract $(n=3)$.

\begin{tabular}{|l|c|c|c|}
\hline Compound & $\begin{array}{c}\text { Added concentra- } \\
\text { tions }(\boldsymbol{\mu g} / \mathbf{m L})\end{array}$ & Recovery & RSD \% \\
\hline $\mathbf{4}$ & 50 & 105 & 0.55 \\
\hline $\mathbf{5}$ & 20 & 103 & 0.17 \\
\hline $\mathbf{6}$ & 50 & 104 & 6.83 \\
\hline
\end{tabular}

in the extract as well as a large amount of very polar constituents, mainly sugars, not retained on $\mathrm{C}_{18}$ (RT $2.6 \mathrm{~min}$ ). The PDA and MS spectra of these main constituents enabled the dereplication of 6 as the flavonoid $C$ glycoside gendarusin A (UV PDA spectra: $\lambda_{\max }$ 245, 352 nm; HRMS [M - H] at m/z 533.1347) [11, 12] and peaks $\mathbf{4}$ and $\mathbf{5}$ as the pair of 2-aminobenzyl derivatives, isomeric justidrusamide A or B [13] (UV PDA spectra: $\lambda_{\max } 204,236 \mathrm{~nm}$; HRMS [M - $]^{-}$at $\mathrm{m} / \mathrm{z} 368.1365$ and 368.1374 , respectively).

Other minor constituents still detectable by ELSD were, on one hand, the isomer of gendarusin A, gendarusin $B(7)$, which exhibited the same $\mathrm{m} / \mathrm{z}$ ion and chromophore as compound $\mathbf{6}$ and, on the other hand, three additional 2-aminobenzyl derivatives (1-3) all exhibiting the same chromophore (UV PDA spectra: $\lambda_{\max } 204$, 236 nm; > Fig. 1).

Peaks 2 and 3 displayed [ $\mathrm{M}$ - H]' at m/z 384.1282 and 384.1297 in agreement with the molecular formula $\mathrm{C}_{17} \mathrm{H}_{22} \mathrm{NO}_{9}$ and were dereplicated as the two other isomeric pairs of justidrusamide $\mathrm{C}$ or D $[13,17$ ]. Interestingly, 1 (justidrusamide E) also presented a chromophore of 2-aminobenzyl derivatives and was found to be an isomer of 4 and $\mathbf{5}$ (HRMS [M - H] $]^{-}$at $\mathrm{m} / \mathrm{z}$ 368.1356). The polarity and online data indicated that $\mathbf{1}$ (justidrusamide $\mathrm{E}$ ) was a 2-aminobenzyl derivative that potentially had not been previously described. Since $\mathbf{4}, \mathbf{5}$, and $\mathbf{6}$ were the main compounds found in the leaf ( $\triangleright$ Fig. 1), these three compounds were isolated to be used as standards for their quantitation in the traditional decoction, enriched extract used for clinical trials, and leaf extracts of J. gendarussa used from different Indonesian regions.

In order to unambiguously identify compound $\mathbf{1}$ and to obtain enough amount of the standards for the quantitation of 4-6, a crude methanol extract was fractionated. For an efficient and rational isolation, a direct transfer of the analytical HPLC conditions to MPLC was performed using the same reversed-phase material [18]. This procedure resulted in the isolation of six compounds from $3 \mathrm{~g}$ of crude methanol extract (1, 2, 3, 4-6). Their full de novo identification was performed based on 1D and 2D NMR and HRMS experiments. In accordance with the dereplication results, the identity of recently reported amides [13] justidrusamide $D(2)$, justidrusamide $C(3)$, justidrusamide $A(4)$, and justidrusamide $B(5)$ and the main flavonoid gendarusin $A(6)[11,12]$ was confirmed. In addition, 1 was found to be a new 2-aminobenzyl derivative and, as indicated from dereplication, probably a new compound not previously described. Its identification is described below.

Compound 1 was isolated as an amorphous solid. The ESI-HRMS spectrum showed a molecular ion at $\mathrm{m} / \mathrm{z} 368.1356$ [M - H]', (calcd. for $\mathrm{C}_{17} \mathrm{H}_{22} \mathrm{NO}_{8}, 368.1345 ; \Delta \mathrm{ppm}=3.0$ ). The NMR data of 1 showed strong similarities with those of justidrusamide $D(2)$ [13]. The data

> Table 4 Retention time reproducibility of justidrusamide A (4), justidrusamide B (5), and gendarusin A (6) in five different J. gendarussa leaf preparations extracted and analysed separately $(n=3)$.

\begin{tabular}{|c|c|c|c|c|c|c|}
\hline & $\begin{array}{c}\text { Purwodadia } \text { RT }^{\mathbf{c}} \\
\text { RSD }^{\mathrm{d}}\end{array}$ & Cibodas a RT RSD & Gempola RT RSD & Pacet $^{\text {a }}$ RT RSD & $\begin{array}{c}\text { Water }^{\mathrm{b}} \text { decoction } \\
\text { RT RSD }\end{array}$ & $\begin{array}{c}\text { Enriched }^{\mathrm{b}} \text { extract } \\
\text { RT RSD }\end{array}$ \\
\hline 4 & 18.590 .04 & 18.620 .04 & 18.600 .04 & 18.650 .36 & 18.620 .02 & 18.680 .04 \\
\hline 5 & 20.690 .04 & 20.670 .12 & 20.690 .04 & 20.700 .08 & 20.720 .02 & 20.790 .05 \\
\hline 6 & 23.250 .05 & 23.310 .08 & 23.270 .06 & 23.280 .12 & 23.300 .02 & 23.390 .05 \\
\hline
\end{tabular}

a. gendarussa leaves from Purwodadi, Cibodas, Gempol, and Pacet regions in Indonesia. ${ }^{b}$ Water decoction and enriched extract prepared from J. gendarussa leaves. cMean retention time (min). dRelative standard deviation (\%) 


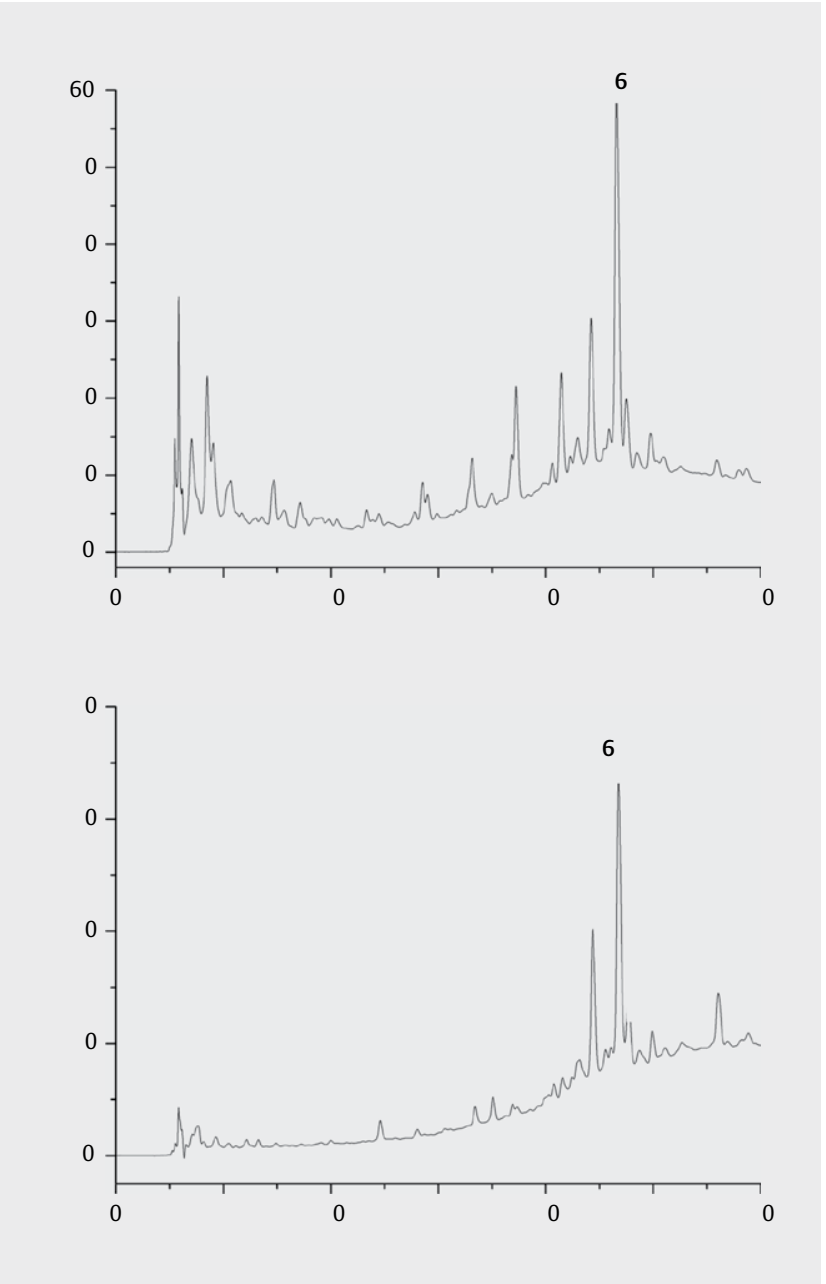

- Fig. 3 HPLC-PDA-ESLD analysis of J. gendarussa-enriched extract and water decoction.

was indeed consistent with the presence of a 5-hydroxy-2-aminobenzyl alcohol group $\left[\delta_{\mathrm{H}} 6.76(1 \mathrm{H}, \mathrm{dd}, \mathrm{J}=8.5,2.9 \mathrm{~Hz}, \mathrm{H}-4), 7.00\right.$ $(1 \mathrm{H}, \mathrm{d}, \mathrm{J}=2.9 \mathrm{~Hz}, \mathrm{H}-6), 7.05(1 \mathrm{H}, \mathrm{d}, \mathrm{J}=8.5 \mathrm{~Hz}, \mathrm{H}-3)$, and $4.94(2 \mathrm{H}$, s, $\mathrm{H}-17)]$ and a 2,3-dihydroxy-2-(1-hydroxyethyl) butanoic acid group $\left[\delta_{\mathrm{H}} 1.04\left(3 \mathrm{H}, \mathrm{d}, \mathrm{J}=6.4 \mathrm{~Hz}, \mathrm{CH}_{3}-13\right), 1.05(3 \mathrm{H}, \mathrm{d}, \mathrm{J}=6.4 \mathrm{~Hz}\right.$, $\left.\mathrm{CH}_{3}-11\right)$, and $\left.3.88(2 \mathrm{H}, \mathrm{q}, \mathrm{J}=6.4 \mathrm{~Hz}, \mathrm{H}-10,12)\right]$. Compound 1 differed from 2 at the level of the succinic acid moiety where an additional methine was observed at $\delta_{\mathrm{H}} 5.14\left(1 \mathrm{H}, \mathrm{d}, \mathrm{J}=4.5 \mathrm{~Hz}, \mathrm{H}-4^{\prime}\right)$ and $\delta_{\mathrm{C}}$ 93.0. The COSY correlation between $\mathrm{H}-4$ ' and the methylene $\mathrm{CH}_{2}-3^{\prime}\left[\delta_{\mathrm{H}} 2.33\right.$ and 2.54] between $\mathrm{CH}_{2}-3^{\prime}$ and $\mathrm{CH}_{2}-2^{\prime}\left[\delta_{\mathrm{H}} 2.00\right.$ and 2.33] as well as the $\mathrm{HMBC}$ correlations from $\mathrm{H}-4$ ' to $\mathrm{CH}_{2}-3^{\prime}\left[\delta_{\mathrm{C}}\right.$ $28.4]$ and to the ester carbonyl $\mathrm{C}-1$ ' $\left[\delta_{\mathrm{C}} 174.2\right.$ ] indicated that the succinic acid was cyclised in $\mathbf{1}$ to form a hydroxy-oxopyrrolidin group. Based on these results, 1 was identified as 5-hydroxy-2-(2hydroxy-5-oxopyrrolidin-1-yl)benzyl(3 R)-2,3-dihydroxy-2-((R)1-hydroxyethyl)butanoate, a new 2 -aminobenzyl derivative named justidrusamide E ( Fig. 2).

The HPLC-UV method developed for the qualitative profiling was used for the quantitation of the three main metabolites (4-6) and for comparison of the content of various extracts (see experiment). The method was validated for linearity, limits of detection (LOD),

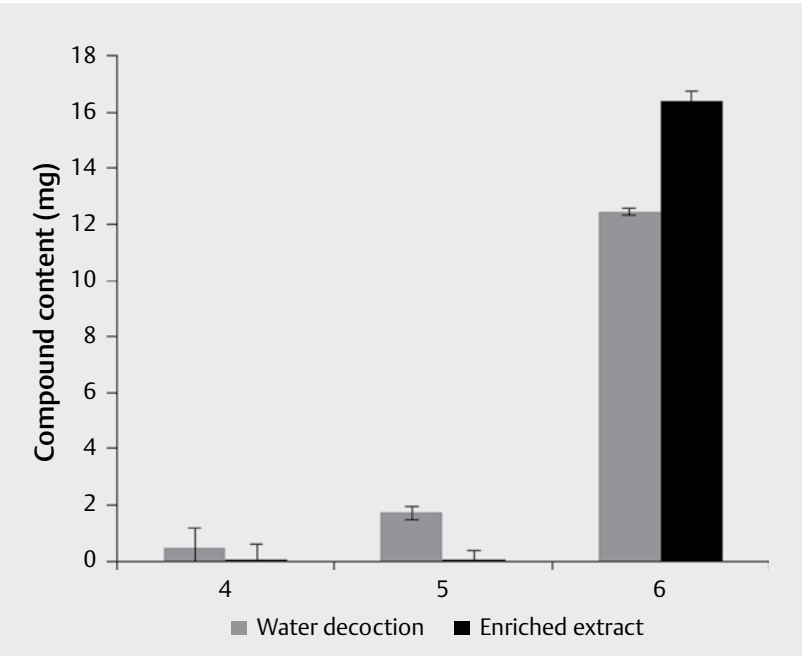

-Fig. 4 Comparison of the justidrusamide A (4), justidrusamide B (5), and gendarusin $\mathrm{A}(\mathbf{6})$ amounts $(\mathrm{mg}, \mathrm{w} / \mathrm{w})$ found in $1 \mathrm{~g}$ dry leaf of J. gendarussa used for the decoction and in the clinical pill containing an enriched extract $(450 \mathrm{mg}) ; \mathrm{n}=3$.

limits of quantification (LOQ), and for precision and accuracy using already isolated and identified compounds (see above) [19].

The linearity range for each compound was measured at a minimum of six different concentrations on each calibration curve $(n=6)$. Calibration curves were constructed by plotting injected concentrations of the standard analytes $(\mathrm{X})$ vs. their peak areas $(\mathrm{Y})$. Good linearity was observed by the linear regression analyses in a large range of concentrations: $1-800 \mu \mathrm{g} / \mathrm{mL}$ for compound 4 $\left(R^{2}=0.999\right), 1-800 \mu \mathrm{g} / \mathrm{mL}$ for compound $5\left(R^{2}=0.998\right)$, and $1-100 \mu \mathrm{g} / \mathrm{mL}$ for compound $\mathbf{6}\left(R^{2}=0.998\right)$ ( $\triangleright$ Table $\left.\mathbf{1}\right)$.

The LOQ and LOD were calculated by determining the standard deviation of the response and the slope of the linear equation. LOD was found to be $0.008,0.013$, and $0.293 \mu \mathrm{g} / \mathrm{mL}$ for $\mathbf{4}, \mathbf{5}$, and $\mathbf{6}$, respectively, and the corresponding LOQ was $0.024,0.039$, and $0.889 \mu \mathrm{g} / \mathrm{mL}$ for $\mathbf{4}, \mathbf{5}$, and $\mathbf{6}$, respectively (

The precision of the assay was determined by measuring intraday (repeatability) and inter-day (intermediate) variations (expressed as RSD \%) at three concentrations included on the calibration curve ( $\triangleright$ Table 2 ). These solutions were prepared independently from the calibration solutions. Intraday variation was determined by analysing six replicates of known concentrations using the same preparation procedure within a single day $(n=6)$. Inter-day precision was determined in duplicate on 3 consecutive days $(n=6)$. The RSD\% of the peak areas and retention times were calculated and the results are summarised in ₹ Table 2 .

The intraday and inter-day RSD \% did not exceed the allowed $15 \%$, which is in accordance with the bioanalytical method validation guidelines of the Food and Drug Administration [19]. Matrix effects were evaluated using recovery studies by the standard addition method. Known concentrations of standard compounds (4 and 6 at $50 \mu \mathrm{g} / \mathrm{mL}, 5$ at $20 \mu \mathrm{g} / \mathrm{mL}$ ) were spiked into a pre-analysed J. gendarussa methanol crude extract $(1000 \mu \mathrm{g} / \mathrm{mL})$ and reanalysed ( $\triangleright$ Table 3). The mean recovery for all compounds was $95 \%$ and 


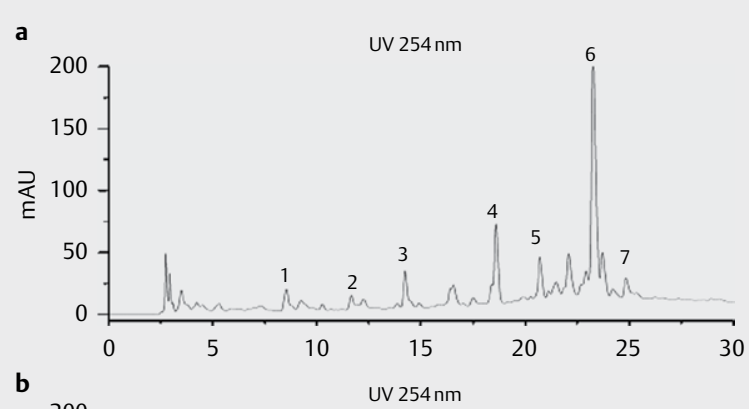

b

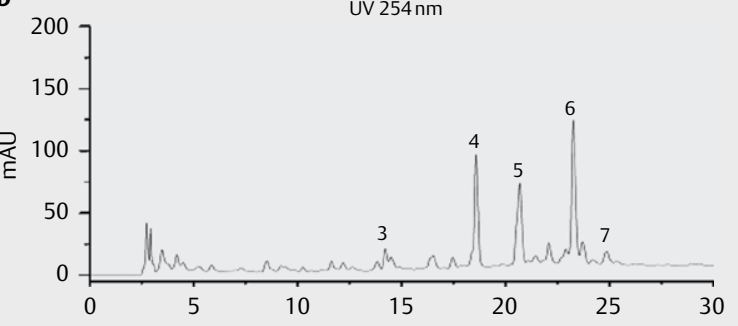

C
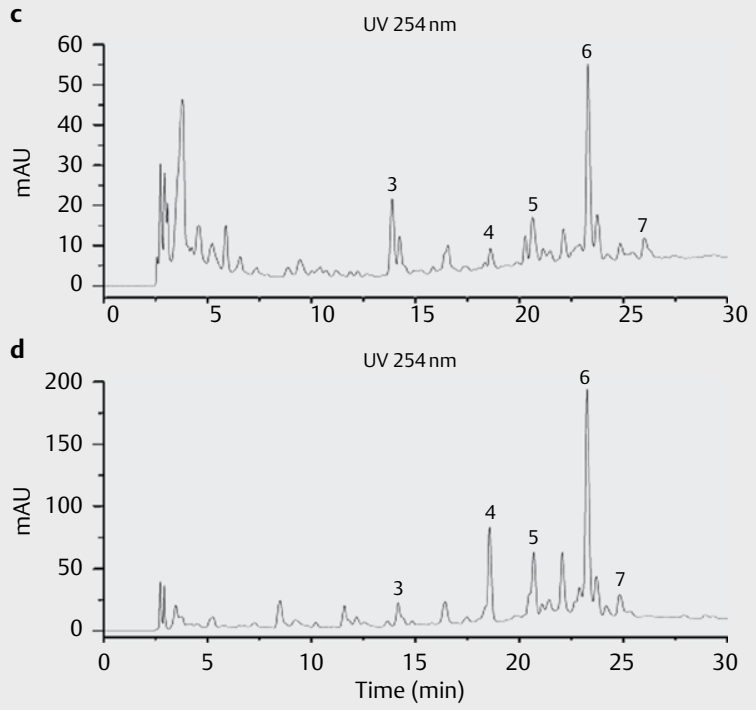

> Fig. 5 HPLC-UV analysis $(254 \mathrm{~nm})$ of J. gendarussa methanol extracts from a Purwodadi, b Gempol, c Cibodas, and $\mathbf{d}$ Pacet.

within the acceptable upper limit of $120 \%$ (105, 103, and $104 \%$ for compounds 4, 5, and 6, respectively; > Table 3).

For method reproducibility, the water decoction, enriched extract, and methanol extracts of J. gendarussa from various regions were analysed using the validated method. Results expressed as RSD \% of the mean RT of compounds $\mathbf{4}, \mathbf{5}$, and $\mathbf{6}(n=3)$ indicated good reproducibility of the method (RSD \% $<1 \%$; $>$ Table 4 ).

Comparison of the UV profiles of the water decoction and en-

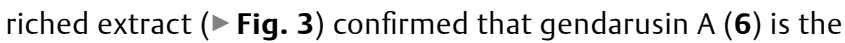
major compound in both of the extracts. Furthermore, UV and ELSD results indicated that $\mathbf{4}$ and $\mathbf{5}$ (justidrusamides $A$ and $B$ ) were at negligible amounts in the enriched extract, while the decoction still contained both in significant amounts. In the ELSD trace of the enriched extract, the peaks corresponding to the 2-aminobenzyl derivatives (1-3) were not detected. These results suggest that the acid-base extraction used for the preparation of the enriched extract for clinical studies removes the amides (see experiment). In

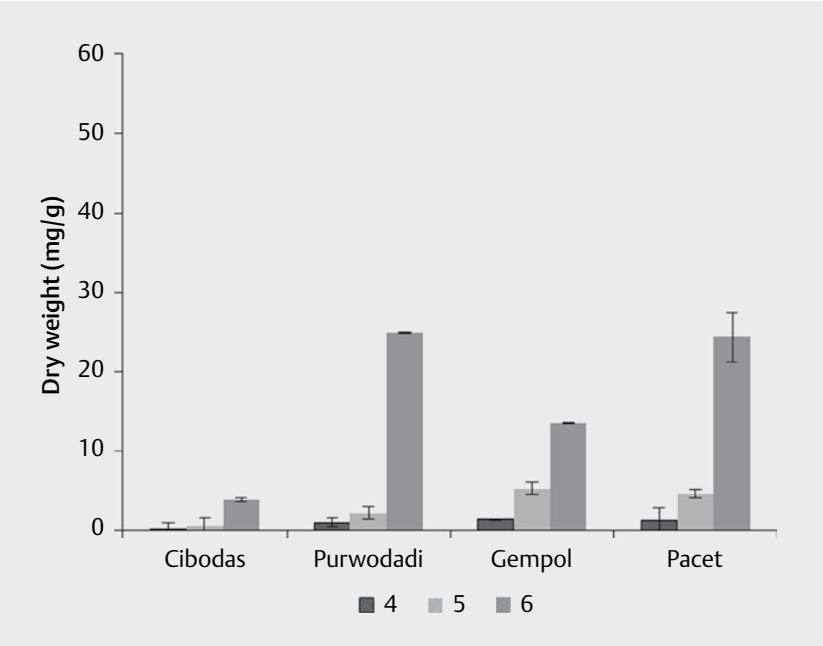

Fig. 6 Amounts of justidrusamide $A(4)$, justidrusamide $B(5)$, and gendarusin $A(6)(\mathrm{mg}, \mathrm{w} / \mathrm{w})$ found in $1 \mathrm{~g}$ dry leaf of $\mathrm{J}$. gendarussa from Cibodas, Purwodadi, Gempol, and Pacet; $\mathrm{n}=3$.

the trials, the enriched extract was used once daily at a $450-\mathrm{mg}$ dosage, indicating that the volunteers received $16.40 \mathrm{mg} \pm 1.26$, w/w active compound gendarusin A (6) daily, while compounds 4 and 5 were kept at very low concentrations $(0.01 \mathrm{mg} \pm 0.52$ and $0.05 \mathrm{mg} \pm 0.05, \mathrm{w} / \mathrm{w}$, respectively). Furthermore, as can be seen in - Fig. 4, the enriched extract at a 450-mg dosage still contained more active gendarusin $\mathrm{A}(16.40 \mathrm{mg} \pm 1.26)$ than the $1 \mathrm{~g}$ dry leaf (12.45 mg \pm 0.79 ) used for the decoction preparation, highlighting that the enriching process during the extraction is an important step to secure a high content of the active compound in the final yield.

The water decoction presented a similar qualitative profile to that of the methanol extracts ( $\triangleright$ Fig. 1S, Supporting Information). In order to facilitate future selection of J. gendarussa plant specimens with the highest content of the active principle $\mathbf{6}$, different samples were compared. Dry leaves from various regions in Indonesia (Purwodadi, Gempol, Cibodas, and Pacet) were exhaustively extracted by methanol (see experiment). For quantitation, all samples were prepared at $10 \mathrm{mg} / \mathrm{mL}$ through appropriate dilution of the stock solutions in $70 / 30, \mathrm{v} / \mathrm{v} \mathrm{MeOH}-\mathrm{H}_{2} \mathrm{O}$ (see experiment). The HPLC-UV comparison of the methanol extracts revealed that qualitatively all plants contained 1-7 ( $\mathbf{\text { Fig. }} \mathbf{5}$ ) and that the influence of the geographic origin did not seem to be very significant in the constituent makeup.

Though the gendarusin A (6) remained the main constituent in all extracts, the amounts were different in all four types of leaves. Purwodadi and Pacet dry leaves contained similarly high amounts of the active compound $\mathbf{6}$ ( $\triangleright$ Fig. $\mathbf{6}$ ), while leaves of the Cibodas had the lowest content. Similar results have been reported elsewhere [17]. By contrast, Pacet and Gempol showed similar amounts of $\mathbf{5}$ (justidrusamide B). Such variation between the quantitative profiles of $J$. gendarussa leaves might be explained by the effect of cultivation practices in different geographical regions in accordance with previous reports [17].

Therefore, to have the highest antifertility effectiveness, it is necessary to have $J$. gendarussa leaves from the regions highest in 
gendarusin A, i. e., Purwodadi and Pacet. However, more studies on the effects of seasonal variations on the quantitative content of gendarusin A should be undertaken. The gendarusin A content was also found to be higher in the enriched extract containing the pill used for the clinical studies, but lesser than the extracts, which can be explained by the different extraction protocols used.

Overall, J. gendarussa leaves had similar chemical qualitative profiles independent from the geographical regions in Indonesia, however, they were quantitatively different. Cibodas leaves had the lowest amount of the active principle, gendarusin A (6), with about fourfold less flavonoid than the sample collected in Purwodadi, which is most probably due to the geographical region of cultivation (soil, temperature, etc.). The extract used in clinical trials contained mainly gendarusin A, as for the traditional decoction, but the level of the aminobenzyl derivatives was significantly lower. Qualitatively, all compounds isolated from J. gendarussa leaves were found in the traditional preparation (decoction). The water decoction still contained significant, although lesser amounts, of the active compound $\mathbf{6}$ compared to both the extracts and enriched extracts, which is encouraging for traditional users when taking into consideration their relatively simple method of preparation. Nevertheless, the decoction also contained aminobenzyl derivatives, which were absent in the enriched extract, and therefore the toxicology of these compounds should be considered in order to mitigate any delayed adverse effects amongst traditional users.

\section{Materials and Methods}

\section{General experimental procedures}

UV spectra were measured on a PerkinElmer Lambda 20 spectrophotometer. NMR spectroscopic data were recorded on a $500 \mathrm{MHz}$ Varian Inova spectrometer. Chemical shifts are reported in parts per million $(\delta)$ using the residual $C_{3} \mathrm{OD}$ signal $\left(\delta_{\mathrm{H}} 3.31 ; \delta_{\mathrm{C}} 49.0\right)$ or DMSO- $d_{6}$ signal $\left(\delta_{\mathrm{H}} 2.50 ; \delta_{\mathrm{C}} 39.5\right)$ as internal standards for ${ }^{1} \mathrm{H}$ and ${ }^{13} \mathrm{C} \mathrm{NMR}$, and coupling constants (J) are reported in $\mathrm{Hz}$. Complete assignment was performed based on 2D experiments (COSY, TOCSY, NOESY, edited-HSQC, and HMBC). ESI-HRMS data were obtained on a Micromass LCT Premier time-of-flight mass spectrometer from Waters with an electrospray ionisation (ESI) interface. Analytical HPLC was performed using an HP 1100 system equipped with a photodiode array detector (Agilent Technologies) using an X-Bridge RP $C_{18}$ column $(5 \mu \mathrm{m}, 250 \times 10 \mathrm{~mm}$, i.d.; Waters). MPLC was performed using a modular Büchi MPLC system equipped with a 681 pump module C-615, UV-Vis detector module C-640, and Fraction collector module C-660, as well as a $460 \times 70 \mathrm{~mm}$ i.d. column (Büchi) loaded with Zeoprep ${ }^{\circledR} \mathrm{C}_{18}$ as the stationary phase (15$25 \mu \mathrm{m}$; Zeochem).

\section{Chemicals}

HPLC-PDA-ESI-MS analysis was performed with $\mathrm{H}_{2} \mathrm{O}$ (Millipore) and MeOH HPLC grade (Fisher Scientific). UPLC-TOF-HRMS analysis was performed with $\mathrm{H}_{2} \mathrm{O}$ and acetonitrile UPLC-MS grade (Biosolve). MPLC-UV isolation was performed with $\mathrm{H}_{2} \mathrm{O}$ (Millipore) and $\mathrm{MeOH}$ (technical grade). The MS was calibrated using sodium formate and leucine-enkephalin, both from Sigma-Aldrich. In HPLC, MPLC, and
HRMS analyses, formic acid (FA) was used as the organic modifier (Sigma-Aldrich).

\section{Plant material}

Leaves of J. gendarussa werre collected in Pacet (East Java), Purwodadi (East Java), Cibodas (West Java), and Gempol (East Java), Indonesia, in the period between 2012 and 2013 by Prof. B. Prajogo. The botanical material was identified by the Indonesian Institute of Sciences (LIPI). A voucher specimen was deposited at the Pharmaceutical Botany Laboratory, Faculty of Pharmacy, Universitas Airlangga, Surabaya, Indonesia. The voucher numbers are:J. gendarussa collected in Surabaya No 03/2012; J. gendarussa collected in Purwodadi No 05/2012; J. gendarussa collected in Pacet No 04/2012; J. gendarussa collected in Gempol No 01/2012; J. gendarussa collected in Cibodas $N^{\circ} 07 / 2013$. The dried leaf powder upon receipt was stored in a cold, dark, ventilated room.

\section{Increasing polarity extraction}

The dried leaf powder of J. gendarussa $(200 \mathrm{~g})$ collected in Pacet (Mojokerto, East Java) was extracted using mechanical agitation by maceration with solvents in the order of increasing polarity: hexane, dichloromethane, methanol, and water, respectively. The exhaustiveness of the extraction was monitored by thin-layer chromatography using the Godin reagents [20]. The extracts were filtered and concentrated to dryness by rotatory evaporation to yield $3.86 \mathrm{~g}$ of hexane $(1.93 \%, \mathrm{w} / \mathrm{w}), 2.54 \mathrm{~g}$ of dichloromethane $(1.27 \%$, $\mathrm{w} / \mathrm{w}), 20.07 \mathrm{~g}$ of methanol ( $10.03 \%, \mathrm{w} / \mathrm{w})$, and $37.91 \mathrm{~g}$ of water extract $(18.95 \%, w / w)$. The methanol extract was used for the metabolite profiling and isolation of the standards for quantitation.

The dried leaf powders of J. gendarussa from Purwodadi $(2.13 \mathrm{~g})$, Cibodas (2.00 g), and Gempol (2.08g) were extracted using the same procedure described above to produce a methanol extract yield ( \%) as follows: Purwodadi (9.03\%, w/w), Cibodas $(5.94 \%$, $\mathrm{w} / \mathrm{w})$, and Gempol ( $8.48 \% ; 16.38 \%, \mathrm{w} / \mathrm{w})$. The dried extracts were kept at $4{ }^{\circ} \mathrm{C}$ until the analyses were performed. Samples were filtrated with a $0.45-\mu \mathrm{m}$ membrane filter prior to the HPLC analyses.

\section{Water decoction preparation}

The dried ground leaf powder (150 g) was soaked in boiling water (600 mL; Millipore) under reflux for $1 \mathrm{~h}$ and then filtered under a vacuum pump. The filtrate was lyophilised to produce the water decoction extract ( $18.64 \%$ yield, w/w). The water decoction was prepared to mimic the traditional preparation process used by the Papua populations in Indonesia [9].

\section{Enriched extract used in clinical trials}

The enriched extract used in the clinical studies was a dosage of a capsule containing $450 \mathrm{mg}$ of the dry $70 \%$ ethanol leaf extract $[12,17]$. These capsules were prepared and delivered by the Department of Pharmacognosy and Phytochemistry, Faculty of Pharmacy, University of Airlangga. The protocol for using the capsules in the clinical trials requires the administration of one capsule a day for 30 days.

For the purpose of dereplication, an enriched extract was prepared according to the same acid-base extraction procedure used for the clinical trials [12]. J. gendarussa leaf powder collected in Pacet, Mojokerto, East Java, Indonesia was macerated with acidi- 
fied water, $(100 \mathrm{~mL}, \mathrm{pH} 3, \mathrm{HCl}) 3 \times 24 \mathrm{~h}$ using a shaker at room temperature $\left(20 \pm 3^{\circ} \mathrm{C}\right)$. The plant material residue was washed with running water until it reached a $\mathrm{pH}$ of 6 . An aliquot of the residue was extracted with $70 \%$ ethanol $(3 \times 24 \mathrm{~h})$ by maceration and checked for the presence of alkaloids by TLC, using Dragendorff until the results were negative [20]. The filtrate obtained was evaporated at $40^{\circ} \mathrm{C}$ using a rotary evaporator (Büchi). This process obtained a $70 \%$ ethanol extract of the $J$. gendarussa leaves. The dried extract was kept at $4{ }^{\circ} \mathrm{C}$ until the analyses were performed. HPLCPDA-ELSD analyses revealed that the enriched extract obtained was qualitatively similar to the capsules used in the clinical studies (results not shown).

\section{HPLC-PDA-ELSD analysis}

HPLC-PDA-ELSD analyses were conducted on an HP 1100 system equipped with a photodiode array detector (Agilent Technologies) connected to an ELSD Sedex 85 (Sedere). The HPLC conditions were as follows: X-Bridge $C_{18}$ column $(250 \times 4.6 \mathrm{~mm}$ i.d., $5 \mu \mathrm{m}$, Waters $)$; solvent system $\mathrm{MeOH}(\mathrm{B})$ and $\mathrm{H}_{2} \mathrm{O}(\mathrm{A})$, both containing $0.1 \% \mathrm{FA}$; gradient elution $0 \min 5 \% \mathrm{~B}, 5$ to $20 \% \mathrm{~B}$ in $10 \mathrm{~min}, 20 \%$ to $100 \% \mathrm{~B}$ in $30 \mathrm{~min}$. Flow rate $1 \mathrm{~mL} / \mathrm{min}$; injection volume $10 \mu \mathrm{L}$; sample concentration $10 \mathrm{mg} / \mathrm{mL}$ in the mobile phase. The UV absorbance was measured at $254 \mathrm{~nm}$ and the UV-PDA spectra were recorded between 190 and $600 \mathrm{~nm}$ (step $2 \mathrm{~nm}$ ). The ELSD detection parameters were as follows: pressure $3.5 \mathrm{bar}, 45^{\circ} \mathrm{C}$, split to provide a 500 $\mu \mathrm{L} / \mathrm{min}$ flow rate, gain 8 . This method was used for the profiling and main components' quantitation.

\section{UHPLC-TOF-HRMS analysis}

UPLC-TOF-HRMS analyses were performed on a Waters Acquity UPLC system coupled to a Waters Micromass-LCT Premier time-offlight mass spectrometer, equipped with an electrospray interface (ESI). The ESI conditions were as follows: capillary voltage $2800 \mathrm{~V}$, cone voltage $40 \mathrm{~V}$, MCP detector voltage $2400 \mathrm{~V}$, source temperature $120{ }^{\circ} \mathrm{C}$, desolvation temperature $300{ }^{\circ} \mathrm{C}$, cone gas flow $20 \mathrm{~L} / \mathrm{h}$, desolvation gas flow $600 \mathrm{~L} / \mathrm{h}$. Detection was performed in the negative ion mode with an $\mathrm{m} / \mathrm{z}$ range of 100-1000 Da and a scan time of $0.5 \mathrm{~s}$ in the $\mathrm{W}$-mode. The MS was calibrated using sodium formate. Leucine enkephalin (Sigma-Aldrich) was used as an internal reference at $2 \mu \mathrm{g} / \mathrm{mL}$ and infused through a Lock Spray probe at a flow rate of $10 \mu \mathrm{L} / \mathrm{min}$ aided by a second LC pump. The separation was performed on an Acquity BEH $C_{18}$ UHPLC column $(50 \times 1 \mathrm{~mm}$ i.d., $1.7 \mu \mathrm{m}$; Waters) using a linear gradient of $\mathrm{H}_{2} \mathrm{O}(\mathrm{A})$ and acetonitrile (B), both containing $0.1 \% \mathrm{FA}$. The gradient elution was from 5 to $95 \% \mathrm{~B}$ in $4 \mathrm{~min}$ and the flow rate was $0.3 \mathrm{~mL} / \mathrm{min}$. The temperature was set at $30^{\circ} \mathrm{C}$ and the injection volume was setat $1 \mu \mathrm{L}$.

\section{Compound isolation}

The HPLC conditions used for the gradient transfer to MPLC (reversed-phase medium-pressure liquid chromatography) were as follows: Zeoprep $C_{18}$ column $(250 \times 4.6$ mm i.d., $15-25 \mu \mathrm{m}$; Zeochem); mobile phase: $\mathrm{H}_{2} \mathrm{O}(\mathrm{A})$ and $\mathrm{MeOH}(\mathrm{B})$, both containing $0.1 \%$ FA; gradient elution: $0-5 \%$ of $B$ in 3 min followed by $20 \%$ for 23 min, hold $20 \%$ B for $5 \mathrm{~min}$ ( $25 \mathrm{~min}$ ), increase $B$ until $30 \%$ during next $10 \mathrm{~min}$ ( $38 \mathrm{~min}$ ), hold $30 \% \mathrm{~B}$ for $10 \mathrm{~min}$ ( $48 \mathrm{~min}$ ), increase B content until $35 \%$ for $10 \mathrm{~min}$ ( $58 \mathrm{~min}$ ), hold $35 \%$ until $75 \mathrm{~min}$, at $78 \mathrm{~min} \mathrm{~B}$ content is $50 \%$, hold for $10 \mathrm{~min}(88 \mathrm{~min})$, increase $B$ to $70 \%$ (98 min), hold $70 \%$ B for the next $10 \mathrm{~min}$, and, finally, increase B level until it is $100 \%(118 \mathrm{~min})$. The flow rate was $1 \mathrm{~mL} / \mathrm{min}$. The injection volume was $20 \mu \mathrm{L}$ and the sample concentration was $10 \mathrm{mg} /$ $\mathrm{mL}$ in the mobile phase. The samples were analysed with UV detection, and the absorbance was measured at $254 \mathrm{~nm}$ and ELSD detection. The ELSD detection parameters were as follows: pressure 3.5 bar, $45^{\circ} \mathrm{C}$, split to provide a $500-\mu \mathrm{L} / \mathrm{min}$ flow rate, gain 8 .

The crude methanol extract $(3 \mathrm{~g})$ was fractionated using MPLC with Zeoprep $C_{18}(920 \times 49 \mathrm{~mm}$ i.d., $25 \mu \mathrm{m}$, Zeochem); mobile phase: $\mathrm{MeOH}(\mathrm{B})$ and $\mathrm{H}_{2} \mathrm{O}(\mathrm{A})$, both containing $0.1 \% \mathrm{FA}$ as the mobile phase in gradient mode, as above. The flow rate was $8 \mathrm{~mL} / \mathrm{min}$, and the UV absorbance was detected at $254 \mathrm{~nm}$. In total, $300 \mathrm{frac}-$ tions were collected. All fractions were analysed using UPLC-TOFMS. The purity of compounds 1-7 was estimated using HPLC-ELSD and UPLC-TOF-MS (results not shown), and the ELSD profiles of compounds 4-6 are shown in > Fig. 9S, Supporting Information.

\section{Compound characterization}

Justidrusamide $E(\mathbf{1})$. Amorphous white powder. $[\alpha]_{D} 20+4.1^{\circ}(c$ 0.96, MeOH); UV (MeOH); $\lambda_{\max }(\log \varepsilon) \mathrm{nm}: 220$ (sh), $276(4.8) .{ }^{1} \mathrm{H}$ NMR (DMSO-d, $500 \mathrm{MHz}) \delta 1.04\left(3 \mathrm{H}, \mathrm{d}, \mathrm{J}=6.4 \mathrm{~Hz}, \mathrm{CH}_{3}-13\right), 1.05$ $\left(3 \mathrm{H}, \mathrm{d}, \mathrm{J}=6.4 \mathrm{~Hz}, \mathrm{CH}_{3}-11\right), 2.00(1 \mathrm{H}, \mathrm{t}, \mathrm{J}=10.4 \mathrm{~Hz}, \mathrm{H}-2 \mathrm{\prime} b), 2.33(2 \mathrm{H}$, m, H-2'a, 3'b), $2.54(1 \mathrm{H}, \mathrm{m}, \mathrm{H}-3$ 'a), $3.88(2 \mathrm{H}, \mathrm{q}, \mathrm{J}=6.4 \mathrm{~Hz}, \mathrm{H}-10$, 12), $4.94(2 \mathrm{H}, \mathrm{s}, \mathrm{H}-7), 5.14(1 \mathrm{H}, \mathrm{d}, \mathrm{J}=4.5 \mathrm{~Hz}, \mathrm{H}-4$ '), $6.76(1 \mathrm{H}, \mathrm{dd}$, $\mathrm{J}=8.5,2.9 \mathrm{~Hz}, \mathrm{H}-4), 7.00(1 \mathrm{H}, \mathrm{d}, \mathrm{J}=2.9 \mathrm{~Hz}, \mathrm{H}-6), 7.05(1 \mathrm{H}, \mathrm{d}$, $\mathrm{J}=8.5 \mathrm{~Hz}, \mathrm{H}-3) .{ }^{13} \mathrm{C}$ NMR (DMSO-d $\left.6,126 \mathrm{MHz}\right) \delta 17.7(\mathrm{C}-11,13)$, 24.7 (C-2'), 28.4 (C-3'), 62.2 (C-7), 68.5 (C-10, 12), 83.2 (C-9), 93.0 (C-4'), 114.7 (C-4), 115.1 (C-6), 126.7 (C-2), 128.9 (C-3), 135.2 (C1), 156.9 (C-5), 173.8 (C-8), 174.2 (C-1'). ESI-HRMS m/z 368.1356 $[\mathrm{M}-\mathrm{H}]^{-}$(calcd. for $\mathrm{C}_{17} \mathrm{H}_{22} \mathrm{NO}_{8}{ }^{-}, 368.1345, \Delta \mathrm{ppm}=3.0$ ).

\section{Preparation of samples for quantitation}

Standard stock solutions $(1000 \mu \mathrm{g} / \mathrm{mL})$ of compounds $\mathbf{4}, \mathbf{5}$, and $\mathbf{6}$ were prepared separately by accurately weighing $10 \mathrm{mg}$ of each compound, transferring them into a volumetric flask $(10 \mathrm{~mL})$, and dissolving them in $10 \mathrm{~mL}$ of methanol under sonication (1 min). Working solutions were prepared through serial dilutions of the stock solutions in 70/30, v/v MeOH- $\mathrm{H}_{2} \mathrm{O}$ in the range of concentrations for the calibration curve covering 1 to $800 \mu \mathrm{g} / \mathrm{mL}$ for each compound [21]. Water decoction, enriched extract, and methanol extract stock solutions were prepared by accurately weighing $200 \mathrm{mg}$ of each sample, transferring them into a volumetric flask $(10 \mathrm{~mL})$, and dissolving them in methanol $(10 \mathrm{~mL})$ under sonication (1 min). Working solutions $(10 \mathrm{mg} / \mathrm{mL}$ ) were prepared using appropriate dilution of the stock solution in $70 / 30, v / v ~ M e O H-H_{2} O$. All samples were prepared daily before the analyses. All samples were prepared not earlier than a day before the analyses and were kept at $4{ }^{\circ} \mathrm{C}$. All samples were filtered through a $0.45-\mu \mathrm{m}$ membrane filter before injection into the HPLC system.

\section{Supporting information}

HPLC-UV chemical profiles of the J. gendarussa methanol leave extract from various regions in Indonesia and water decoction, ${ }^{1} \mathrm{H}$ NMR spectrum of compound $\mathbf{1}$, and COSY NMR spectrum of compound $\mathbf{1}$ are available as Supporting Information. 


\section{Acknowledgements}

The authors are thankful to the Swiss State Secretariat for Education Research and Innovation (SERI) for the financial support of this project (Grant 2013-0483 to M.M.).

\section{Conflict of Interest}

The authors declare no conflict of interest.

\section{References}

[1] Thomas TD, Yoichiro H. In vitro propagation for the conservation of a rare medicinal plant Justicia gendarussa Burm. F. by nodal explants and shoot regeneration from callus. Act Physiol Plant 2010; 32: 943-950

[2] Basah K, Elya B, Amin J, Julian MI. Activity of ethanolic extract from Justicia genderussa Burm. leaves on decreasing the uric acid plasma. Mak J Sci 2011; 15: 61-70

[3] Corrêa GM, Alcaântara AFC. Chemical constituents and biological activities of species of Justicia - a review. Rev Bras Farmacogn 2012; 22: $220-238$

[4] Kadir MF, Bin Sayeed MS, Setu NI, Mostafa A, Mia MM. Ethnopharmacological survey of medicinal plants used by traditional health practitioners in Thanchi, Bandarban Hill Tracts, Bangladesh. J Ethnopharmacol 2014; 155: 495-508

[5] Paval J, Kaitheri SK, Potu BK, Govindan S, Kumar RS, Narayanan SN, Moorkoth S. Anti-arthritic potential of the plant Justicia gendarussa Burm F. Clinics (Sao Paulo) 2009; 64: 357-362

[6] Jothimanivannan C, Kumar RS, Subramanian N. Anti-inflammatory and analgesic activities of ethanol extract of aerial parts of Justicia gendarussa Burm. Int J Pharmacol 2010; 6: 278-283

[7] Krishna KL, Jagruti AP. Antioxidant and hepatoprotective activity of Justicia gendarussa Burm. Indian J Pharmacol 2008; 40: 69-69

[8] Handayani L. A male contraceptive pill consist of gandarusa (Justicia gendarussa Burm. F). J Indones Med Assoc 2007; 57: 279-284

[9] Moeso S, Agus P. Report of the trip to the Jayapura Sentani (Irian Jaya). Yogyakarta: Faculty of Biology, Gadjah Mada University; 1985: 19

[10] Prajogo EWB, Ifadotunnikmah F, Febriyanti AP, Jusak N. Effect of Justicia gendarussa Burm.f. leaves water fraction on male rabbit liver and renal fuction (Sub acute toxicity test of Justicia gendarussa Burm.f. leaves water fraction as male contraceptive agent). Veterinaria Medika 2008;1-3: 79-82
[11] Prajogo BEW, Guliet D, Queiroz EF, Wolfender JL, Cholies NZ, Aucky H, Hostettmann K. Isolation of male antifertility compound in N-butanol fraction of Justicia gendarussa Burm. F. leaves. Folia Med Indones 2009; 1: 28-31

[12] Sihabuddin M, Maria A, Flourisa JS, Pramesti B, Musta'ina S, Radjaram A, Aucky H, Prajogo BEW. Pharmacokinetic parameters determination of gendarusin $A$ in men subject urine after administration of ethanol extract of Justicia gendarussa Burm. f. leaf (ethno medicine research). J Med Planta 2011; 1: 59-68

[13] Kiren Y, Deguchi J, Hirasawa Y, Morita H, Prajogo B, Justidrusamides A-D. new 2-aminobenzyl alcohol derivatives from Justicia gendarussa. J Nat Med 2014; 68: 754-758

[14] Chakravarty AK, Dastidar PPG, Pakrashi SC. Simple aromatic-amines from Justicia gendarussa. ${ }^{13} \mathrm{C}$ NMR spectra of the bases and their analogs. Tetrahedron 1982; 18: 1797-1802

[15] Satapathy AK, Gunasekaran G, Sahoo SC, Amit K, Rodrigues PV. Corrosion inhibition by Justicia gendarussa plant extract in hydrochloric acid solution. Corros Sci 2009; 51: 2848-2856

[16] Lin Y, Mahan K, Lathrop WF, Myles DG, Primakoff P. A hyaluronidase activity of the sperm plasma-membrane protein $\mathrm{PH}-20$ enables sperm to penetrate the cumulus cell layer surrounding the egg. J Cell Biol 1994; 125: 1157-1163

[17] Ningsih IY, Purwanti DI, Wongso S, Prajogo BEW, Indrayanto G. Metabolite profiling of Justicia gendarussa Burm. f. leaves using UPLC-UHR-QTOF-MS. Sci Pharm 2015; 83: 489-500

[18] Challal S, Queiroz EF, Debrus B, Kloeti W, Guillarme D, Gupta MP, Wolfender JL. Rational and efficient preparative isolation of natural products by MPLC-UV-ELSD based on HPLC to MPLC gradient transfer. Planta Med 2015; 81: 1636-1643

[19] Food and Drug Administration. Bioanalytical method validation, guidance for industry. U.S. Department of Health and Human Services, Food and Drug Administration. Available at https://www.fda.gov/ downloads/drugs/guidances/ucm368107.pdf. Accessed March 7, 2014

[20] Wagner H, Bladt S. Plant drug analysis: A thin layer chromatography atlas. $2^{\text {nd }}$ ed. Dordrecht: Springer; 2009

[21] de Amorim MR, Rinaldo D, do Amaral FP, Vilegas W, Magenta MAG, Vieira GM, dos Santos LC. HPLC-DAD based method for the quantification of flavonoids in the hydroethanolic extract of Tonina fluviatilis Aubl. (Eriocaulaceae) and their radical scavenging activity. Quim Nova 2014; 37: 1122-1227 